Милена Ивановић

Филолошки факултет Универзитета у

Београду

Катедра за славистику

ivanovic.milena@gmail.com
УДК 81 '255.4:821.161.2-1(=163.41) https://doi.org/10.18485/slavistika.2021.25.1.7

Оригинални научни рад примљено 11.05.2021.

прихваћено за штампу 17.06.2021.

\title{
МИОДРАГ СИБИНОВИЋ КАО ПРЕВОДИЛАЦ УКРАЈИНСКЕ ПОЕЗИЈЕ
}

\begin{abstract}
Чланак је посвећен доприносу Миодрага Сибиновића представљању украјинске књижевности у српској културној средини кроз превођење украјинске поезије. Током 20 година М. Сибиновић објавио је како у периодици тако и у посебним издањима преводе хиљада стихова преко сто аутора, међутим, његов допринос не огледа се само у обиму преводилачког опуса, већ, пре свега, у квалитету превода поетских дела различитих епоха и разноликих израза. У другом делу рада анализирамо Сибиновићево преводилачко мајсторство на примеру превода уводног дела баладе Тараса Шевченка „Зачарана“.

Кључне речи: украјинска поезија, превођење, садржај, форма, метар, ритам, рима, еуфонија, стилска средства.

This article is dedicated to Miodrag Sibinović's contribution to the presentation of Ukrainian literature in the Serbian cultural environment through his translation of Ukrainian poetry. For 20 years M. Sibinović published, both in periodicals and in poetry collections or anthologies, translations of thousands of verses by more than a hundred authors. However, his contribution is reflected not only in the large number of translated poems but above all in the quality of these translations, which is impressive considering that the translated poetic works belong to different epochs and represent poets of various expressions. In the second part of the article we analyze Sibinović's translation skills on the example of the translation of Taras Shevchenko's ballad "Bewitched".
\end{abstract}

Keywords: Ukrainian poetry, translations, content, form, meter, rhyme, rhythm, euphony, stylistic means.

Селективна библиографија радова професора Миодрага Сибиновића објављена поводом 80 година његовог живота у XXI књизи часописа Славистика (Јаковљевић-Радуновић и др. 2017: 34-57) броји преко 450 наслова и обухвата монографске публикације, приређена издања, научне радове објављене у периодици и зборницима, хронику, приказе и критике, као и преводе. Предани професор, темељит теоретичар и историчар књижевности, ванредан теоретичар превођења и надахнути преводилац - слависта у правом смислу те речи, широких интересовања и назора, Миодраг Сибиновић обогатио је српску преводну књижевност и културу уопште бројним тумачењима и преводима дела најистакнутијих словенских писаца, пре свега песника - о чему сведочи и поменута библиографија. Међу тим делима значајно место заузима и поезија украјинских песника, којој је професор Сибиновић посветио делове двеју монографских публикација - Иза хоризонта: огледи из руске, украјинске, белоруске и грузијске кьижевности (Сибиновић 2002) и Словенска вертикала: српске, руске, белоруске и украјинске књижевне теме (Сибиновић 2008), двадесетак чланака објављених како у научној (часописи, зборници конефернција), тако 
и у књижевној (Савременик плус, Српски књижевни гласник, Кюижевне новине итд.) и популарној (културни додатак Политике) периодици. Сибиновићев допринос представљању украјинске књижевности српском читаоцу, међутим, огледа се пре свега у његовим бриљантним преводима хиљада стихова преко стотине украјинских аутора.

Од шездесет година, колико је трајала славистичка каријера Миодрага Сибиновића, интересовање за украјинску књижевност испољава се у последњој трећини тог периода. Наиме, године 1993. објавио је своје прве преводе украјинске поезије, ${ }^{1}$ и то у часопису Савременик плус - поетска дела украјинских песника 20. века, од којих су неки у Србији, како запажа Т. Гаев, представљени први пут - М. Семенко, М. Руденко, Б. Бојчук и др. (Гаев 2019: 11), а у Српском књижевном гласнику - српској читалачкој публици, такође по први пут, представљена је старија украјинска поезија - од 16. до 18. века, као и стихови двојице у то време савремених украјинских песника В. Кордуна и И. Драча. У истом броју Српског кюижевног гласника Сибиновић је објавио и први, краћи, чланак о украјинској поезији „Заједничка традиција или универзалност људске природе“ (Сибиновић 1993a: 33-34), а у Савременику плус још један - „У инат ветровима: уз нове преводе из савремене украјинске поезије, осврт на српско-украјинске везе у XVIII, XIX и XX веку“ (Сибиновић 1993б: 431-437). Последњи чланак посвећен украјинској књижевности „Место украјинске књижевности у српској науци о књижевности и култури“ објавио је 2017. године, симболично - у зборнику Украјинистика и словенски свет објављеном поводом 25 година украјинистике на Универзитету у Београду, чијем је развоју и сам дао немерљив допринос (Сибиновић 2017: 45-62). Последњи превод са украјинског језика објавио је нешто раније, 2013. године шест песама Леса Белеја, представника млађе генерације украјинских песника, у часопису Руковет (Belej 2013: 80-81). ${ }^{2}$

Дакле, током двадесет година Сибиновићеви преводи украјинске поезије објављивани су у српској периодици - у Савременику плус, Српском књижевном гласнику, Книжевној речи, Развитку, Писму, Пролому, Книжевним новинама, Трагу, Тиси, Градини и и Руковети. Многи од њих ушли су у Антологију украјинске поезије XVI-XX века: У инат ветровима, објављену 2002. године у Бањалуци (Поповић 2002). Антологију је приредила Љ. Поповић, која је такође аутор предговора, коментара и дела превода, док је већину превода сачинио М. Сибиновић, из чијег пера је изашао и поговор. Антологија обухвата 74 украјинска песника, од чега је М. Сибиновић превео стихове њих 68, као и не-

${ }^{1}$ По речима самог Миодрага Сибиновића своју прву украјинску песму, стихове И. Драча Ждребе, превео је двадесетак година раније (Сибиновић 2017: 45-46).

${ }^{2}$ Ови преводи нису ушли ни у библиографију коју својој докторској дисертацији прилаже Т. Гаев, јер се она завршава 2007. годином, ни у селективну библиографију објављену у часопису Славистика 2017. године.

${ }^{3}$ Преводи песама Л. Костенко, И. Драча, В. Стуса, В. Кордуна и других, објављени 2001. године у нишком часопису за књижевност, уметност и културу Градина, такође нису ушли у селективну библиографију, али су представљени у докторској дисертацији Т. Гаев. 
колико песама анонимних аутора из 16. и 17. века. ${ }^{4}$ Годину дана касније, такође у Бањалуци, изашла је из штампе збирка поезије В. Кордуна Песме (Кордун 2003). Све стихове у овој збирци одабрао је и превео Миодраг Сибиновић. Треба поменути и избор и превод љубавне лирике у који је ушла поезија чак 102 украјинска песника који су стварали од 17. до 20. века објављен 2001. године (Sibinović 2001). У овом за представљање украјинске књижевности у Србији плодном периоду објављен је још један избор из поезије Т. Шевченка Кобзар (Шевченко 2006). У избор од 70 песама, који је сачинила приређивач и аутор преговора Љ. Поповић, заједно са преводима Љ. Симовића, Д. Максимовић, Л. Хајдуковића, Ј. Хрваћанин и других, ушло је чак 24 Сибиновићева превода. Исте године у издању Националног савета Украјинаца изашао је у Новом Саду један сигнални примерак антологије поезије репресованих украјинских песника Жигосани коју су заједно приредили Љ. Поповић и М. Сибиновић, док је аутор превода стихова репресованих украјинских песника 20. века Миодраг Сибиновић.

Међутим, пуко набрајање Сибиновићевог преводилачког опуса у домену украјинске поезије, иако је број преведених стихова свакако импресиван и импозантан, као и чињеница да је успео да у српском језику нађе адекватан израз песницима различитих периода, праваца и сензибилитета, говоре много, али не и све о његовом преводилачком умећу. Главни показатељ доприноса који је Миодарг Сибиновић дао представљању украјинске поетске речи у српској преводној књижевности крије се у квалитету његових превода, у изузетној способности успостављања еквиваленције између оригинала и превода кроз танану равнотежу садржаја и форме преведених песничких дела. У свом говору са промоције добитника Повеље за животно дело Удружења књижевника Србије 2012. године, књижевник и преводилац Н. Бертолино каже: „Много је примера који показују Сибиновићево преводилачко мајсторство, изузетну способност 'читања' оригинала и препознавања његових вредности, али и располагање могућностима и лепотама свог језика“ и наводи ,један од најубедљивијих примера“ - превод Љермонтовљеве песме „Выхожу один я на дорогу...“ (Бертолино 2012). Много је таквих примера и када су у питању преводи украјинске поезије, а неке од њих - преводе песме украјинског бароконог песника И. Величковског „Ехо“ и стихова симболисте Ј. Савченка „Христос отаву косио“ - наводи и Љ. Поповић у монографији Фокусна перспектива украјинске књижевности (Поповић 2007: 89). Ми ћемо у овом раду покушати да представимо Сибиновићево мајсторство и сагледамо вредност његовог преводилачког опуса на једном примеру (а свакако их има много више) из класичне украјинске поезије - преводу уводног дела романтичарске баладе Тараса Шевченка „Зачарана“ („Причинна“).

Пре него што приступимо анализи, треба истаћи да професор Сибиновић није био само преводилац, већ и теоретичар и историчар превођења. Иза њега је остало мноштво радова објављених у периодици и више засебних

\footnotetext{
4 За преводе објављене у овој антологији добио је награду „Иван Франко“ коју за превођење и популаризацију украјинске књижевности у свету додељује Национално удружење књижевника Украјине (Поповић 2007: 88).
} 
публикација на којима су стасавале и стасавају генерације филолога и преводилаца. У истраживањима из ове области Сибиновића су посебно интересовала питања превођења поезије и вредновања поетских превода. Од раних покушаја успостављања објективних критеријума оцењивања превода поезије на примерима превода песме А. Вознесенског „Жена у августу“ (Сибиновић 1979: 158171) или Симовићевог превода песме Ј. Баратинског „Натпис” (Сибиновић 1982), преко анализе Винаверових превода „Дванаесториц““ А. Блока (Сибиновић 2009: 242-286), Змајевог и Бертолинијевог превода Љермонтовљевог „Демона“ (Sibinović 2015: 72-124), све до последњег, детаљног и бриљантног осврта на Кишов и Раичковићев превод песме „Лењинград“ О. Мандељштама (Сибиновић 2018), Миодраг Сибиновић непрестано, као да му за то упорно није довољно сопствено богато преводилачко искуство, настоји да проникне у тајне превођења поезије, да одреди научно засноване и објективне параметре вредновања поетских превода и, најзад, формира „нешто ширу скицу развоја српског књижевног преводилаштва“ (Сибиновић 2018: 223). У том смислу наш рад није само омаж Сибиновићу - књижевном преводиоцу, већ и Сибиновићу теоретичару превођења.

Питање преводивости окупира књижевнике, преводиоце, лингвисте, филозофе од давнина. Немогућност превођења уопште везује се за различитост језичких слика света и изражена је, на пример, у ставовима В. фон Хумболта, А. Потебње или Е. Сапира и Б. Ворфа (Ивлева и др. 2018), а посебно се везује за превођење поезије. Још је Данте у својој Гозби упозоравао преводиоце да не гаје превише самопоуздања када се лаћају превода поезије, а Сервантес оваквим размишљањима говори кроз уста својих јунака, па читамо, рецимо, да је преводилац делу „много узео од његове природне вредности; а то често чине и сви они, који књиге у стиховима хоће да преводе на други језик, јер крај све брижљивости, коју залажу, и вештине, коју показују, никада неће ону висину постигнути, коју они имају на свом првом језику“ (Сервантес 1895: 35). ${ }^{5}$ Сам Сибиновић такође је разматрао различите ставове према преводивости поезије, истичући да „на плану ритмичког и звуковног уобличавања песничког исказа најјаче долази до израза природа језика на којем се тај исказ уобличава“ те да су „разлике између језика оригинала и језика превода често толико непремостиве да лако могу сугерисати становиште о непреводивости поезије“ (Сибиновић 1979: 150). Међутим, запажа он, преводилачка пракса показује другачије. Негирање могућности процеса који се одвија већ вековима и који има много заиста врхунских резултата заправо је само одраз тешкоћа са којима се сваки преводилац среће, а преводилац поезије поготово. Између дијаметрално супротних концепција непреводивости и свепреводивости - ако је у општем смислу прва повезана са теоријама језичке релативности, друга је повезана са теоријама језичких универзалија (Ивлева и др. 2018) - развија се концепција степена преводивости. Будући да поезија представља по свему посебан тип текста, за нас је овде интересантан приступ савремене руске теоретичарке И. Алексејеве по коме сваки тип текста има свој степен преводивости. Тај степен (I, II или III) одређује се постојањем непреводивих компоненти у њему

\footnotetext{
${ }^{5}$ О томе детаљније пише Н. Гарбовски (Гарбовский 2007: 111-112).
} 
(Алексеева 2004: 262). Међу таквим компонентама, поред оних које су одраз различитости језичких слика света, ${ }^{6}$ издвајају се оне проузроковане тзв. „Конфликтом форме и садржаја“, које настају онда „када је значењских особености форме веома много и тешко их је пренети све заједно, мада се свака појава понаособ може пренети“ - а до оваквог конфликта долази пре свега у поезији „те није случајно да су најчешће управо поетски текстови у различитим периодима сматрани непреводивим“ (Алексеева 2004: 263).

Говорећи о поезији као посебном, примарно естетском типу текста, И. Алексејева даље наглашава да „ни у једном другом тексту игра форме нема тако велики значај, нигде другде естетске информације нису представљене толиком концентрацијом средстава као у поезији“ (Алексеева 2004: 318). Уколико у језику оригинала и језику превода постоје традиције употребе сличног система версификације, Алексејева као задатак преводиоца види да се „потруди“ да пренесе: 1. врсту и број стопа, евентуалне измене броја стопа у стиховима; 2. каденцу, односно мушки, женски или дактилски тип риме; 3. дистрибуцију риме; 4. еуфонију и 5. број и место лексичких и синтаксичких понављања (Алексеева 2004: 318-319). То - што се тиче формалне стране стихова. Што се тиче садржинске стране, И. Алексејева истиче „да не треба мислити да при превођењу стихова доминирају само компоненте поетске форме“, те у циљу преношења целокупног система поетских слика преводилац треба да настоји и да пренесе стилиску изнијансираност лексике, место лексеме у стиху, стилске фигуре, игре речи, лексички контраст и сл. (Алексеева 2004: 319).

Да видимо, дакле, на који начин је Миодраг Сибиновић успео да усклади форму и садржај поетске речи у свом преводу пролога баладе Тараса Шевченка „Зачарана“ и како је успео да пренесе основну, естетску, функцију песме, јер се судови о стварном значају превода у поступку било каквог „суптилнијег“ вредновања могу донети, како истиче сам Сибиновић, „са становишта адекватности укупног естетичког утиска који ствара превод“ (Сибиновић 1982: 49).

Пролог Шевченкове баладе написан је четворостопним јамбом са елементима дибраха, којим се у више од половине стихова замењује трећа стопа. Покретна и динамичка природа украјинског акцента пружа украјинским песницима слободу употребе различитих врста метричких стопа. Природа српског акцента, који се не може наћи на последњем и чешће се појављује на првом слогу, условљава трохејску интонираност српског језика, ${ }^{7}$ што знатно отежава

${ }^{6}$ Такве компоненте могу бити ситуативне реалије, концепти који одражавају рашчлањивање стварности својствено датој култури, егзотизми и сл. (Алексеева 2004: 262).

7 Погледајмо, на пример, са каквом је лакоћом Сибиновић доследно пренео метар у једној другој украјинској песми написаној четворостопним трохејем - стиховима М. Семенка. Ови стихови такође су изванредан пример преношења еуфонијске организације поетског дела:

Білі білі як коралі

білі зуби зуби Галі

тіло біле все у неї

тіло білої лілеї

вона вся така пестлива

повна чарів повна дива
Беле беле од корала

беле зубе има Гаља

тело бело она има

тело бело као љиьан

сва је мазна нежна свуда

пуна чари пуна чуда 
превођење стихова сачињених у јампском метру. Овога је Миодраг Сибиновић и те како свестан - узмимо, на пример, његову опаску у анализи Симовићевог превода песме Ј. Баратинског да је „слабљење јампске основе у односу на руску, у исказу на српскохрватском језику скоро неизбежна појава“" и закључак да „уколико је јамб у преводу сачуван као метрички сигнал (...) то у свести нашег читаоца (...) ипак изазива естетички утисак адекватан томе утиску који оригинал оставља“ (Сибиновић 1982: 49). Очигледно је Сибиновић преводећи Шевченкове стихове себи за циљ поставио очување јампске тенденције, у чему je, поткован теоријски, али и практично - бројним ранијим преводима источнословенске поезије, и успео. Упоредимо ли прва четири стиха оригинала и превода, видећемо да у српском преводу јамб није очуван само у првој стопи другог стиха. Тиме је пренета динамичност метра и дочаран ударни, трагични ритам узбурканих природних стихија, што управо одговара песничкој слици на почетку пролога. Јампска тенденција у преводу даље слаби и то се опет углавном тиче прве стопе, док се у трећој, као и код Шевченка, јамб често замењује дибрахом. Овакав лабавији јамб, међутим, не одудара од садржаја стихова, у чијем другом делу слику узбуркане природе, стењање реке и урлање ветра смењује злослутни мук глувог доба ноћи:

Реве та стогне Дніпр широкий,

Сердитий вітер завива, Додолу верби гне високі, Горами хвилю підійма. I блідний місяиь на ту пору Із хмари де-де виглядав, Неначе човен в синім морі То виринав, то потопав. Ще треті півні не співали, Ніхто нігде не гомонів, Сичі в гаю перекликались, Та ясен раз у раз скрипів.
Широки Дюепар стење, пати, Срдити ветар урла, оре, Повија врбе као влати, Подиже вале као горе. Иу том часу трепераво Месеи кроз облак мрешка сјајем, Као да чун у мору плавом Појављује се и нестаје. Док трећи петли кукурикну, Све замире у муку раном, Сове се само довикују И каткад јасен шкрипне граном.

Ако упоредимо још један превод Шевченкових стихова из давне 1877. године, ${ }^{8}$ који је, с обзиром да је у питању превод целе баладе а не само њеног пролога, ушао и у изборе из Шевченкове поезије 1969, 1980. и 2006. године, а у коме се испољава природнија за српски језик трохејска тенденција, још се пластичније уочава Сибиновићево мајсторство у преношењу ритмичке структуре Тарасовог песничког исказа. Јампски ритам Сибиновић је постигао пре свега употребом тросложних речи са нагласком на другом слогу (Широки, Повија, Подиже, Појављује) на почетку стиха, док код Грчића стихови углавном почињу паровима двосложних речи (Хучи, јечи .../ Дува ветар / Ниско вите /Диже вихор/ Махом вирне итд.):

${ }^{8}$ Аутор превода потписан је као $\Gamma-\hbar$, а ови иницијали по наводима Т. Гаев дешифровани су као Јован Миленко Грчић (Гаев 2019: 83). 
Хучи, јечи широки Дњепар, Дува ветар расрђени, Ниско вите повија врбе, Диже вихор планином; А блед иза облака месеи Махом вирне па се сакрије, Исто чунић у мору сињу Час се губи, час се виђа. Петли трећи певали нису, Нико нигде не ромори, Гајем кликћу поноћне тице И покашто шкрину гране.

Што се тиче риме, у Шевченковом оригиналу имамо унакрсно смењивање риме са женским (ширОкий-висОкі, nОру-мОрі, співАли - перекликАлись) и мушким (завив $A$ - підіймA, виглядАв - потопАв, гомонІв - скрипІв) завршетком као ритмичким изразом контраста између енергије природних сила и спокојства позне ноћи. Рима је, уз то, типично за Шевченка, неправа или приближна. М. Сибиновић је у преводу очувао изворно унакрсно алтернирање риме, али је одустао од мушке клаузе. Морамо претпоставити да је Сибиновић ово урадио свесно будући да, опет због природе акцента, у српском језику последњи слог може бити наглашен само код једносложних речи или у ретким позајмљеницама, те су могућности за остваривање мушке риме веома ограничене. Наиме, у својим анализама туђих превода он замену (руских) мушких нашим женским римама сматра „законитом“, „природном“ и говори о избегавању „баналних“ рима (Сибиновић 1982: 49-50; 2018: 228), те сигурно, „у име неусиљености и свежине“ (Сибиновић 1979: 168) није желео да банализује ни сопствени превод. Енергија ритма донекле је компензована употребом правих рима на местима Шевченкових мушких клауза.

На еуфонијском плану главно средство је алитерација - понављање фонеме $[\mathrm{P}]$ у прва четири стиха. Алитерација прати песничку слику и дочарава одлучну грмљавину узбуркане реке, појачава емоционалност и интензитет: Реве та стогне ДніпР ииРокий / СеРдитий вітеР завива / Додолу веРби гне високі / ГоРами хвилю підійма. Миодраг Сибиновић успешно је пренео звучање оригинала, делом захваљујући фонетској подударности српских еквивалената, делом избором адекватних синонима: ШиРоки ДюепаР стење, пати, / СРдити ветаР уРла, оРе, / Повија вРбе као влати, / Подиже вале као гоРе.

Успешно је пренета и већина других стилских средстава: персонификација, поређење, контраст, понављања, епитети. Шевченкова метафора претворена је у Сибиновићевом преводу у поређење: Горами хвилю підійма - Подиже вале као горе. У првом стиху имамо одступање од инверзије, која је у оригиналу двострука - и на нивоу синтагме, и на нивоу реченице: Реве та стогне Дніпр широкийШироки Дюепар стење, пати. Одустајање од инверзије у преводу проузроковано је померањем тросложног епитета цироки на почетак стиха у циљу постизања јампског метра. Код Шевченка се инверзија среће и у трећем стиху, али ни овде 
није пренета јер је у преводу изостављен епитет високі. Зато неколико стихова даље у преводу имамо инверзију, а у изворнику - не: Неначе човен в синім морі / Као да чун у мору плавом. Иако компензација пропуштене инверзије у преводу није препоручљива, јер је инверзија средство истицања, овде пермутација служи постизању риме са претходним унакрсним стихом: ...mpепераво /...nлавом.

На плану садржаја можемо рећи да превод, упркос ситним одступањима на нивоу појединачних речи или њиховог места у стиху, преноси интенцију песничке поруке. Одступања на плану преношења појединачних лексичких јединица сва су, с једне стране, у функцији постизања одговарајуће форме - метра и риме и, с друге стране, у оквирима уобичајених преводилачких поступака - конкретизације: Ще треті півні не співали - Док трећи петли кукурикну, генерализације: Сичі в гаю перекликались - Сове се само довикују, антонимијског превода: Ніхто нігде не гомонів - Све замире у муку раном и сл. На два места имамо додавања, ради постизања риме: Ніхто нігде не гомонів - Све замире у муку раном ... Та ясен раз у раз скрипів - И каткад јасен шкрипне граном, или и риме, и еуфоније: Сердитий вітер завива - Срдити ветар урла, оре. Сам Сибиновић је о поступку додавања говорио овако: „Додавања текста због риме, разуме се, нису препоручљива, али уколико нема другог излаза, она морају ипак остати у приближним границама одговарајуће песничке слике оригинала““(Сибиновић 2018: 218), што овде и јесте случај јер додавања не нарушавају целовитост песничке слике.

У поезији је јединица превођења увек целокупан текст, између текстова оригинала и превода тешко се може успоставити еквиваленција на нивоу појединачних речи или синтагми, будући да је организација поетског текста потчињена пре свега ритму, метру и рими. Сибиновићев превод можемо сматрати еквивалентним Шевченковом оригиналу, а еквиваленција је у првом реду постигнута на функционалном нивоу, односно на нивоу очувања поетске функције. Грчићев превод исте песме је, што се тиче преношења појединачних лексема и њиховог распореда, много доследнији изворнику, али то је, као што смо видели, праћено великим одступањима од форме. У књизи $O$ превођењу поезије и други огледи Р. Константиновић пише: „Лапидарност песничког израза, збијеност песничке форме, не пружају преводиоцу поезије могућност за много маневрисања. Више но другде у превођењу поезије дилема - форма или садржина? - лажна је. У поезији (треба ли то доказати?) нема садржине без форме. Преводиочев прворазредни задатак најчешће је, дакле, да адекватно пренесе форму изворника“" (Константиновић 2010: 5). И сам Сибиновић истиче да „како је у поезији изузетно наглашен естетички значај посебне организације песничког језика, приликом превођења се, у принципу, мора посвећивати велика пажња еуритмијској, еуфонијској и синтаксичкој структури песничког израза“ (Сибиновић 1979: 150). И. Алексејева свој одељак о поезији као посебном типу текста завршава констатацијом да су код превођења стихова губици неизбежни и да није случајно да често равноправно постоји неколико варијанти превода поетског дела од којих свака има своје губитке. Међутим, закључује она, „поезија је пре свега музикална, зато, како показује историја, у културној баштини опстају они поетски преводи у којима је очувана поетска форма изворника, иако нису пренели све компоненте садржаја“ (Алексеева 2004: 320). Управо такав је анализирани Сибиновићев превод, који звучи природно и лако, 
и у коме су, уз незнатна одступања од садржаја, пренете песничке слике и мотиви изворника, очуване стилске и естетске функције, динамично променљив ритам и звучање оригинала. Сигурни смо да ће у културној баштини српске преводне књижевности, заједно са његовим другим мајсторским преводима како из украјинске, тако и из других словенских књижевности, имати заслужено место.

\section{Цитирана литература}

Алексеева, Ирина С. Введение в переводоведение. Санкт-Петербург: Иностранные языки, 2004.

[Alekseeva, Irina S. Vvedenie v perevodovedenie. Sankt-Peterburg: Inostrannye iâzyki, 2004] Бертолино, Никола. О Миодрагу Сибиновићу као преводиоцу поезије (Запис са промоције добитника Повеље за животно дело Удружења књижевника Србије 2012) <http://www.rastko.rs/rastko/delo/16085> 26.04.2021.

[Bertolino, Nikola. O Miodragu Sibinoviću kao prevodiocu poezije (Zapis sa promocije dobitnika Povelje za životno delo Udruženja književnika Srbije 2012) <http://www. rastko.rs/rastko/delo/16085> 26.04.2021]

Гаев, Тања. Историја рецепције украјинске књижевности у српској култури: докторска дисертација. Београд: Филолошки факултет, 2019.

[Gaev, Tanja. Istorija recepcije ukrajinske književnosti u srpskoj kulturi: doktorska disertacija. Beograd: Filološki fakultet, 2019]

Гарбовский, Николай К. Теория перевода. Москва: Издательство МГУ, 2007.

[Garbovskij, Nikolaj K. Teoriâ perevoda. Moskva: Izdatel'stvo MGU, 2007]

Ивлева, Алина Ю., М. М. Кузнеченкова, Ю. А. Мишарина. «Проблема переводимости-непереводимости в истории развития переводческой мысли». Дневник науки 4, 2018. <http://dnevniknauki.ru/images/publications/2018/4/philology/Ivleva_ Kuznechenkova_Misharina.pdf $>25.04 .2021$.

[Ivleva, Alina Û., M. M. Kuznečenkova, Û. A. Mišarina. «Problema perevodimostineperevodimosti v istorii razvitiâ perevodčeskoj mysli». Dnevnik nauki 4, 2018. $<$ http:// dnevniknauki.ru/images/publications/2018/4/philology/Ivleva_Kuznechenkova_ Misharina.pdf $>$ 25.04.2021]

Јаковљевић-Радуновић, Ана, Ана Голубовић. „Библиографија проф. др Миодрага Сибиновића“. Славистика XXI/1-2, 2017: 34-57.

[Jakovljević-Radunović, Ana, Ana Golubović. „Bibliografija prof. dr Miodraga Sibinovića“. Slavistika XXI/1-2, 2017: 34-57]

Константиновић, Радивоје. О превођењу поезије и други огледи. Нови Сад: Адреса, 2010.

[Konstantinović, Radivoje. O prevođenju poezije i drugi ogledi. Novi Sad: Adresa, 2010]

Поповић, Људмила. Фокусна перспектива украјинске књижевности. Београд: Филолошки факултет, 2007.

[Popović, Ljudmila. Fokusna perspektiva ukrajinske književnosti. Beograd: Filološki fakultet, 2007]

Сибиновић, Миодраг. Оригинал и превод: увод у историју и теорију превођења. Београд: Привредна штампа, 1979.

[Sibinović, Miodrag. Original i prevod: uvod u istoriju i teoriju prevođenja. Beograd: Privredna štampa, 1979] 
Сибиновић, Миодраг. „О вредновању превода лирске песме: на примеру превода Љубомира Симовића песме Ј. Баратинског 'Натпис'“. Међај 4, 1982: 43-51.

[Sibinović, Miodrag. „O vrednovanju prevoda lirske pesme: na primeru prevoda Ljubomira Simovića pesme J. Baratinskog 'Natpis'“. Međaj 4, 1982: 43-51]

Сибиновић, Миодраг. „Заједничка традиција или универзалност људске природе: украјинско-српске књижевне везе“. Српски књижевни гласник 7-8, 1993: 33-34.

[Sibinović, Miodrag. ,Zajednička tradicija ili univerzalnost ljudske prirode: ukrajinskosrpske književne veze“. Srpski književni glasnik 7-8, 1993: 33-34]

Сибиновић, Миодраг. „У инат ветровима: уз нове преводе из савремене украјинске поезије, осврт на српско-украјинске везе у XVIII, XIX и XX веку“. Савременик плус 3-4, 1993: 431-437.

[Sibinović, Miodrag. „U inat vetrovima: uz nove prevode iz savremene ukrajinske poezije, osvrt na srpsko-ukrajinske veze u XVIII, XIX i XX veku“. Savremenik plus 3-4, 1993: 431-437]

Сибиновић, Миодраг. Иза хоризонта: огледи из руске, украјинске, белоруске и грузијске књижевности. Београд: Чигоја штампа, 2002.

[Sibinović, Miodrag. Iza horizonta: ogledi iz ruske, ukrajinske, beloruske i gruzijske književnosti. Beograd: Čigoja štampa, 2002]

Сибиновић, Миодраг. Словенска вертикала: српске, руске, белоруске и украјинске књижевне теме. Београд: Славистичко друштво Србије, 2008.

[Sibinović, Miodrag. Slovenska vertikala: srpske, ruske, beloruske i ukrajinske književne teme. Beograd: Slavističko društvo Srbije, 2008]

Сибиновић, Миодраг. Нови живот оригинала: увод у превођење. Београд: Просвета, Алтера, Удружење научних и стручних преводиоца, 2009.

[Sibinović, Miodrag. Novi život originala: uvod u prevođenje. Beograd: Prosveta, Altera, Udruženje naučnih i stručnih prevodioca, 2009]

Сибиновић, Миодраг. „Место украјинске књижевности у српској науци о књижевности и култури“. [У:] Љ. Поповић (уред.) Украјинистика и словенски свет: зборник научних радова: поводом 25 година украјинистике на Универзитету у Београду. Београд: Филолошки факултет, 2017: 45-62.

[Sibinović, Miodrag. „Mesto ukrajinske književnosti u srpskoj nauci o književnosti i kulturi“. [U:] Lj. Popović (ured.) Ukrajinistika i slovenski svet: zbornik naučnih radova: povodom 25 godina ukrajinistike na Univerzitetu u Beogradu. Beograd: Filološki fakultet, 2017: 45-62]

Сибиновић, Миодраг. „Осип Мандељштам у српском руху и духу: рецепција Мандељштама у српској књижевности и култури“. Славистика XXII/1, 2018: 193-262.

[Sibinović, Miodrag. „Osip Mandeljštam u srpskom ruhu i duhu : recepcija Mandeljštama u srpskoj književnosti i kulturi“". Slavistika XXII/1, 2018: 193-262]

Sibinović, Miodrag. Množenje svetova: ruski pisci u srpskoj prevodnoj književnosti. Beograd: Clio, 2015.

\section{Извори}

Кордун, Виктор. Песме. Градишка: Српско просвјетно и културно друштво Просвјета; Бања Лука: Друштво српско-украјинског пријатељства Републике Српске, 2003. [Kordun, Viktor. Pesme. Gradiška: Srpsko prosvjetno i kulturno društvo Prosvjeta; Banja 
Luka: Društvo srpsko-ukrajinskog prijateljstva Republike Srpske, 2003]

Поповић, Људмила (прир.). У инат ветровима: Антологија украјинске поезије XVIXX век. Бања Лука: Друштво српско-украјинског пријатељства Републике Српске, Српско Сарајево: Завод за уџбенике и наставна средства Републике Српске, 2002.

[Popović, Ljudmila (prir.). U inat vetrovima : Antologija ukrajinske poezije XVI-XX vek. Banja Luka: Društvo srpsko-ukrajinskog prijateljstva Republike Srpske, Srpsko Sarajevo: Zavod za udžbenike i nastavna sredstva Republike Srpske, 2002]

Сервантес, Мигел. Велеумни племић Дон Кихоте од Манче. Први део. Београд: Задужбина И. М. Коларца, $1895<$ http://www.cervantesvirtual.com/descargaPdf/elquijote-en-serbio/> 24.04.2021.

[Servantes, Migel. Veleumni plemić Don Kihote od Manče. Prvi deo. Beograd: Zadužbina I. M. Kolarca, $1895<$ http://www.cervantesvirtual.com/descargaPdf/el-quijote-enserbio/> 24.04.2021]

Шевченко, Тарас. Кобзар. Нови Сад: Савез Русина и Украјинаца Србије, 2006.

[Ševčenko, Taras. Kobzar. Novi Sad: Savez Rusina i Ukrajinaca Srbije, 2006]

Belej, Les. „Etida“; „Kijevska“, „Noću“, „Ptice“, „Tri sna o Kijevu“, „XX vek“. Rukovet: časopis za književnost, umjetnost i društvena pitanja LIX/1/4, 2013: 80-81.

Sibinović, Miodrag (prir.). Pesme o ljubavi: ukrajinski pesnici. Beograd: Paideia, 2001.

\section{Милена Иванович}

\section{МИОДРАГ СИБИНОВИЧ КАК ПЕРЕВОДЧИК УКРАИНСКОЙ ПОЭЗИИ}

\section{Резюме}

Статья посвящена вкладу Миодрага Сибиновича в представление украинской литературы в сербской культурной среде через перевод украинской поэзии. За 20 лет, с 1993 по 2013 год, М. Сибинович опубликовал как в периодических изданиях, так и в поэтических антологиях и сборниках, переводы тысяч стихов более сотни авторов, а до 2017 года он также публиковал статьи, посвященные украинской литературе и ее восприятию в Сербии. Однако его вклад отражается не только в объеме его переводческой работы, но, прежде всего, в качестве перевода поэтических произведений разных эпох и различных выражений. В первой части статьи кратко перечисляются наиболее значительные достижения М. Сибиновича в переводе стихов украинских авторов, а во второй части статьи на примере перевода вступительной части баллады Т. Шевченко «Помешанная» анализируется переводческое мастерство М. Сибиновича. Этот анализ показывает, что М. Сибинович умело разрешил конфликт содержания и формы, одно из самых больших препятствий в переводе поэзии. С точки зрения формы, он успешно передал ямбическую тенденцию и эвфонию оригинала, сохранил перекрестную рифмовку, но отказался от мужских рифм, которые иначе в переводе на сербский язык, в связи с природой ударения, чрезвычайно трудно достичь. Однако энергия ритма несколько компенсирована использованием полных рифм. Большая часть стилистических приемов также успешно передана, а небольшие отклонения в плане отдельных лексем остаются в рамках поэтического образа.

Ключевые слова: украинская поэзия, перевод, содержание, форма, метр, ритм, рифма, звуковая организация, стилистические средства. 